\title{
NARROW-GAUGE RAILWAY \\ AS A TOURIST ATTRACTION ILLUSTRATED BY THE EXAMPLE OF ZACHODNIOPOMORSKIE VOIVODESHIP
}

\section{GRAŻYNA ROSA}

University of Szczecin

Faculty of Management and Economics of Services

Department of Marketing of Services

e-mail: grazyna.rosa@wzieu.pl

JEL CODES

KEYWORDS

ABSTRACT
L92, R49, Z32, Z33

narrow-gauge railway, tourist attraction

The article discusses the essence of a tourist attraction as an element of a tourist product. It was assumed that narrow-gauge railways are often considered a tourist attraction, which is understood as an interesting way of spending free time and learning about monuments and nature, means of transport, as well as an element of the tradition and history of the railway industry.

The aim of this article is to indicate the importance of narrow-gauge railway transport as a tourist attraction as illustrated by the case of Zachodniopomorskie voivodeship. In order to achieve this, desk research method has been applied in respect to available literature and the results of secondary research conducted at the request of the Railway Transport Office and the Central Statistical Office. The analysis covers transport performed by narrow-gauge railways in Poland within the period 2014-2016. The article is of research nature.

\section{Introduction}

Tourism has become a vital element of today's economy. Income generated by this industry is comparable to income achieved in the fuel and advanced technology industries. Tourism industry would not be possible without the worldwide tourism economy scale, involved capital, as well as the number of employees and the complexity of technical processes in transport and hotel 
management. A tourism product manufactured in this industry (Kaczmarek, Stasiak, Włodarczyk, 2010) is broadly understood also in relation to the region.

According to the concept by V.T.C. Middleton (Zdon-Korzeniowska, 2009, p. 13), a regional tourism product comprises the following factors related to destination: attractions and environment, infrastructure and services, availability, image, and price. In this respect, narrow-gauge railways are a part of the area-related tourism product structure, as they are perceived as both an attraction and infrastructure of the destination.

The aim of this article is to indicate the importance of narrow-gauge railway transport as a tourist attraction as illustrated by the case of Zachodniopomorskie voivodeship. In order to achieve this, desk research method has been applied in respect to available literature and the results of secondary research conducted at the request of the Railway Transport Office and the Central Statistical Office. The analysis covers transport performed by narrow-gauge railways in Poland within the period 2014-2016. The article is of research nature.

\section{Tourist attraction as an element of tourism product}

Tourism product, being the subject of supply on the tourism market, has been the subject of analysis of many Polish authors (J. Altkorn, G. Gołembski, B. Meyer, A. Niezgoda, B. Marciszewska, A. Panasiuk, L. Mazurkiewicz, I. Jędrzejczyk, W. Middleton, J. Kaczmarek, A. Stasiak, B. Włodarczyk, M. Zdon-Korzeniowska, P. Zmyślony).

According to W. Middleton (Niezgoda, 2006, p. 65), there could be distinguished the general (total) tourism product, which constitutes an idea, expectation, or mental construction that exist in a tourist's mind at the moment of making a travel decision, and which are also based on an idea of the expected time spent at the place of destination. The other product distinguished by Middleton, i.e. a specific product, should be understood as particular goods and services offered to tourists (cf. Meyer, 2015, pp. 238-240).

These elements are of a diversified character, as they are parts of different levels of tourist area product, which include (Kaczmarek, Stasiak, Włodarczyk, 2002 p. 103):

- heritage, including all elements created as a result of natural processes and human activities, such as the natural environment, culture and tradition, which form the basis for running various types of activities and the functioning of an area,

- infrastructure, including elements created as a result of human activity that is aimed at tourism development, such as tourist and paratourism accommodation or regional events,

- added value, including the attributes of the area that bring satisfaction to tourists, such as the idea or image,

- organization and management, that is, all elements that enable operation of single elements in the form of a coherent whole constituting the tourist area product.

Tourism product of the area of tourist reception (also described as an area tourism product or tourist area product) arises on many levels and consists of various elements that ultimately should 
form a coherent whole that is attractive to tourists (Meyer, 2015, p. 239). The concept of "tourist attraction" is most often considered an element of tourism product (http://www.turystka07.fora.pl/ geografia-turyzmu,32/podstawowe-pojecia-z-geogr-turyzmu-wyklad-ii,154.html):

1. S. Medlik (1995), following the British terminology, associates tourist values and attractions with elements of a tourism product, which attract visitors, and thus play a decisive role in tourists' decisions on choosing a particular area.

2. Z. Kruczek and S. Sacha (1997) consider a tourist attraction as a tourist value enriched by actions aimed at promoting it.

3. M. Nowacki (2000) states that both tourist value and attraction are features or elements of the environment, which evoke interest among tourists and affect the travel decision making process.

4. T. Lijewski, B. Mikułowski, J. Wyrzykowski (2008) consider tourist attractions as tourist values that occur in the natural state or are adapted for use by tourists, who may consider them the object of interest.

According to the dictionary definition, attraction means an especially interesting feature that provides pleasure or entertainment (Uniwersalny..., 2006). One type of attraction is a tourist attraction which is associated with tourism and tourists. It is usually mentioned in the context of buildings, trails, parks, etc. (Rada..., 2018).

According to this definition, narrow-gauge railways can constitute both an attraction of an area as well as an infrastructure element of an area and its added value.

\section{The evaluation and measurements of tourist attractiveness of Polish voivodeships}

Tourist attractiveness of a voivodeship can be measured using the value of voivodeship tourist attractiveness index. Figure 1 presents results of individual voivodeships. The values of tourist attractiveness index in 2016 were determined for each voivodeship using an arithmetic mean of tourist attractiveness index of poviats included in a given voivodeship and cities with poviat rights (c.w.p.r,) in a given voivodeship (Analiza..., 2017).

The most attractive voivodeships in terms of tourism include: Małopolskie, Pomorskie and Dolnośląskie, followed by Śląskie and Zachodniopomorskie - that is, voivodeships located in southern and northern Poland, within the coastal bands of the Baltic Sea. The narrow-gauge railway lines are mainly concentrated there (Department of Statistics, Tourism, Sport, Culture and National Heritage and P. Łysoń, Department of Social Surveys and Living Conditions, http://stat. gov.pl/z-prac-studialnych/opracowania-eksperymentalne/analiza-walorow-turystycznych-powiatow-i-ich-bezposredniego-otoczenia,7,1.html). 


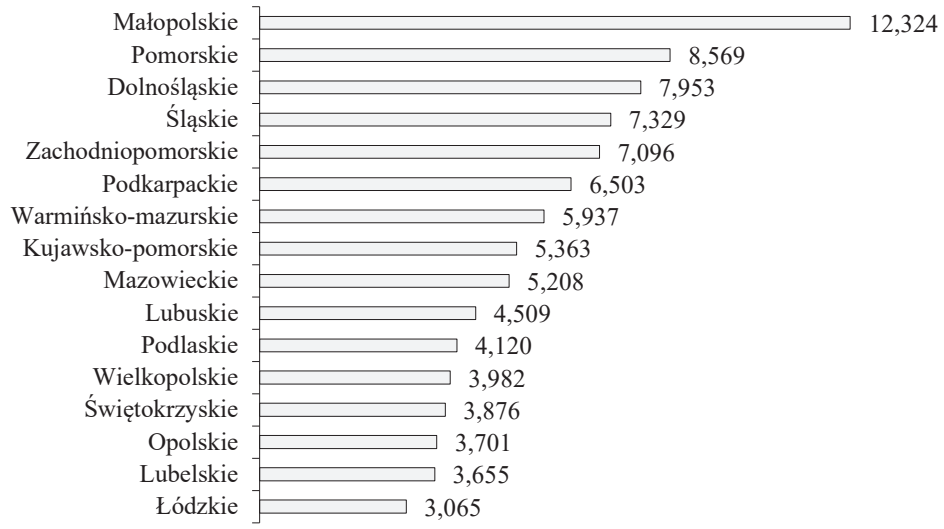

Figure 1. Tourist attractiveness of Polish voivodeships

Source: Information memo 1, the Central Statistical Office (GUS), Warsaw, 20.12.2017 ${ }^{1}$, p. 20. Analiza... (2017).

\section{Narpow-gauge railways in Zachodniopomorskie voivodeship in relation to Poland}

Narrow-gauge railways are characterized by a track gauge (the spacing of the rails) which is narrower than the standard $1.435 \mathrm{~mm}$. Narrow-gauge railways have lower transport capacity than a standard-gauge railway, however, they can include larger inclinations and arcs with a smaller radius, making them even several times cheaper to build.

The origins of narrow-gauge railways in Poland date back to the 19th century. Narrow gauge railway had for a long time played an important complementary role to standard gauge railway. Even in the second half of the twentieth century, it was used both in the scheduled service of passenger traffic and in the transport of goods over short distances. Its advantages, such as the relatively low cost of construction and use of infrastructure, allowed it to be used, among others, in places where the use of standard-gauge infrastructure and rolling stock was unprofitable. Nowadays, narrowgauge railway is only occasionally used for transport of goods. This is mainly due to the intensive development of individual and public road transport. Moreover, its purpose has changed, as it is now used as a tourist attraction that is a part of a given regional tourism product.

In the years 2014-2016, 23 narrow-gauge railways operated in Poland. Its infrastructure varies significantly due to the historical background of every line. In the years 2014-2016, the total length of the railways amounted to $649 \mathrm{~km}$, of which nearly $395 \mathrm{~km}$ were exploited in 2016 . Significantly smaller length of railways used results most often from the poor technical condition

\footnotetext{
${ }^{1}$ The memo updates the research work called "The Analysis of values" of 2005, whose results are available in the publication "Tourism in 2015", with the full report presented at the website of the Central Statistical Office (GUS) http:// stat.gov.pl/statystyka-regionalna/statystyka-dlapolityki-spojnosci/realizacja-prac-metodologicznych-analiz-ekspertyzoraz-prac-badawczych-na-potrzeby-politykispojnosci/inne-prace-badawcze. Project co-financed by the European Union from the funds of the Technical Assistance Operational Programme 2007-2013.
} 
of infrastructure that prevents the use of old routes. The largest number of narrow-gauge railways is located in Mazowieckie voivodeship (over $105 \mathrm{~km}$ ), with only $33 \mathrm{~km}$ of them exploited in 2016.

As previously mentioned, the modern narrow-gauge railway most often constitutes a tourist attraction and cultural heritage that provides the opportunity to travel by exceptional historical rolling stock through places that present special natural and historical values. Statistical data confirm its importance in the Polish tourist landscape. Narrow-gauge railways, which possess a safety certificate issued by the President of the Office of Rail Transport, transport more and more people, mainly for tourist purposes. The number of passengers on these railways increased from 761 thousand in 2015, to almost 948 thousand in 2016 (Kolej..., 2017, p. 2),

This means that tourists are beginning to appreciate the values of narrow-gauge railways, which often become an additional tourist attraction of a given region, and thus a part of its tourism product. The increasing popularity of narrow-gauge railways also brings additional benefits, as it allows to obtain funds for their maintenance and ensure an adequate level of services. In many cases, the actions that guarantee compliance with the above standards require financial support for railway operations that come from public funds, as well as funding for the implementation of projects under the European Funds or the Swiss-Polish Cooperation Program.

Figure 2 shows the increase in the popularity of narrow-gauge railways in Poland, measured by the number of transported passengers per voivodeship.

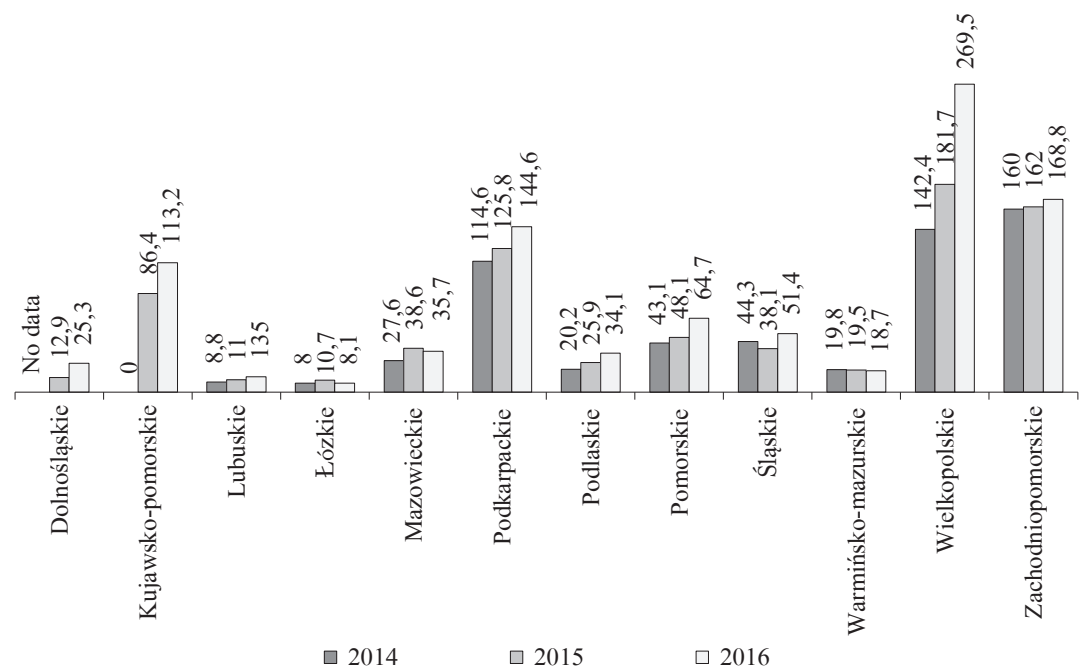

Figure 2. Number of passengers (in thousands) in the years 2014-2016 per voivodeship Source: Kolej... (2017), p. 5.

In 2016, the six biggest narrow-gauge railways transported almost 3/4 of passengers. Among popular railways can be found those whose main advantage is natural conditions, namely Seaside 
Narrow-Gauge Railway (Rewal), Bieszczadzka Forest Railway, Żuławska Suburban Railway, as well as a narrow-gauge railway that constitutes a city attraction, i.e., the Park Railway Maltanka, Pleszewska Narrow-Gauge Railway that resumed their operation in 2015.

The largest number of trains was launched by railways in Wielkopolskie, Zachodniopomorskie, Śląskie and Podkarpackie voivodeships. The number of trains in Wielkopolskie voivodeship results from the operation of the Park Railway Maltanka, which is a city attraction dedicated to children, and regular connections offered every day by Pleszewska Narrow-Gauge Railway. In Podkarpackie and Zachodniopomorskie voivodeships, the biggest number of trains is launched in the summer season, when the tourist traffic and thus a large number of travellers, can be observed, as shown in Figure 3.

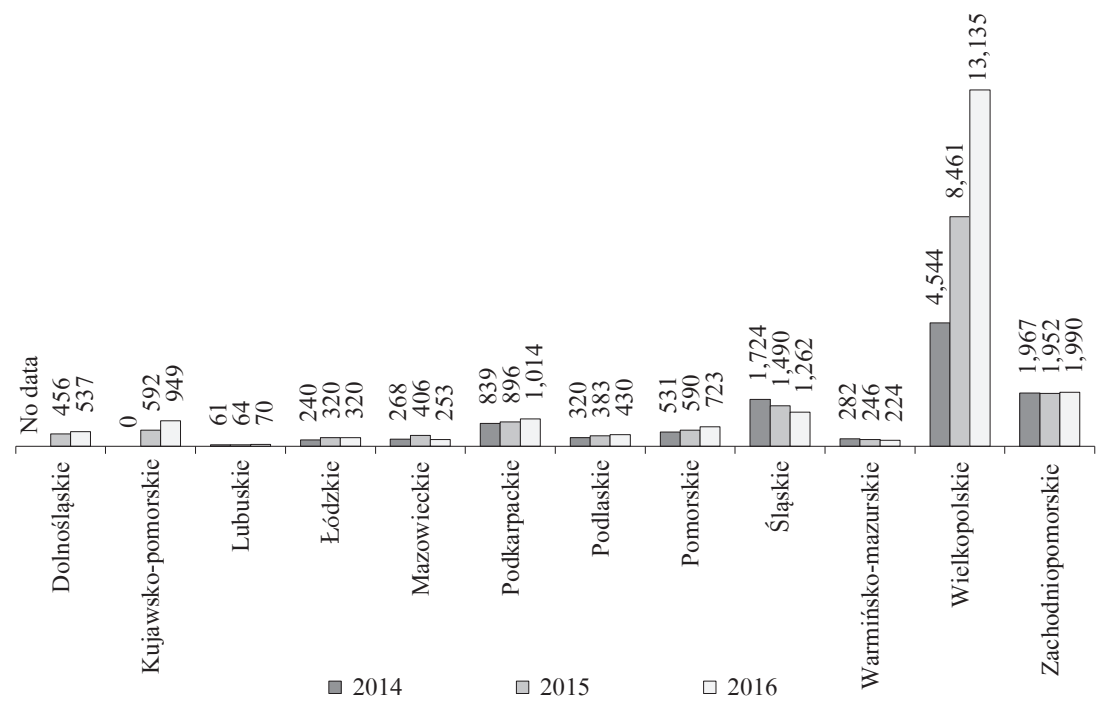

Figure 3. The number of trains launched in the years $2014-2016$ per voivodeship

Source: Kolej... (2017), p. 7.

A characteristic feature of narrow-gauge railways is their considerable diversification, among others, in terms of route length. In 2016, the most exploited narrow-gauge railways were located in Wielkopolskie, Zachodniopomorskie and Podkarpackie voivodeships. The ratio of the exploitation index to the number of trains running is important due to the costs incurred by the organizers of narrow-gauge railways when running longer routes. Railways that offer transport on longer routes run a relatively low number of trains compared to those that offer transport on routes up to several kilometres. This is noticeable, among others, when comparing Wielkopolskie and Podkarpackie voivodeships. The costs of their operation are related to, inter alia, maintenance of narrow-gauge railway infrastructure, vehicles and technical facilities as well as employees' remuneration. 


\section{The characteristics of narpow-gauge railway in Zachodniopomorskie voivodeship}

At the beginning of the 20th century, a narrow-gauge railway network with a total length of $740 \mathrm{~km}$ existed in Pomorze Zachodnie (Western Pomerania) and it was one of the largest of its kind in Europe. In 1945, these railways were taken over by PKP, however, due to the significant war damage and infrastructure theft, some routes were not rebuilt.

The dynamic development of railways at the beginning of the 20th century led to the development of economy of Pomorze Zachodnie region. In the post-war years, rail transport became unprofitable and was dominated by road transport.

The attractiveness of the narrow-gauge railway results from the fact that it constitutes an interesting form of spending free time and learning about monuments or nature, as well as plays a role of everyday means of transport, and, in many cases, a mainstay of tradition and history of the railroading. Very often, the narrow-gauge railway hides "rara avis" of railroading, such as historical vehicles and infrastructure. In most cases, it is the railway transport fans who take care of this heritage form and share their knowledge about the history, construction, and purpose of individual objects (Kolej..., 2017, p. 16).

Nowadays, only two narrow-gauge railways are used in summer, namely Gryfice-Pogorzelica and Koszalin-Manowo. Another route Połczyn Zdrój-Barlinek is already in plans (http://morzeprzygody.eu/?page_id=567).

Nadmorska Kolej Wąskotorowa (Seaside Narrow-Gauge Railway) started operating on the route from Gryfice to Niechorze on 1 July 1896. At the beginning, trains ran on $750 \mathrm{~mm}$ spacing rails. As late as in 1912, rail spacing was widened to $1,000 \mathrm{~mm}$, which significantly facilitated freight transport between Gryfice and Niechorze. Due to the lack of investment, the infrastructure and rolling stock of narrow-gauge railway underwent gradual devastation. To prevent its total destruction, Gryficka Kolej Dojazdowa was entered into the register of historic monuments in 1995. This, however, did not change its poor condition, and when in the 90 s the maintenance of the Gryfice-Trzebiatów railway line was no longer profitable, PKP decided to close the line. In 2002, the local government of the Rewal commune signed a contract with the Directorate of PKP and the Minister of the Treasury on the takeover against payment of the rolling stock together with the infrastructure and Gryfice-Trzebiatów railway line, whose total length amounted to $61 \mathrm{~km}$ (http:// morzeprzygody.eu/?page_id=567).

The new perspective and chance to develop Rewal railway occurred as late as in 2004, after Poland's accession to the European Union, when Rewal municipality, in cooperation with the West Pomerania Marshal's Office, applied for EU subsidies and started one of the greatest investments of recent years - revitalization of Seaside Narrow-Gauge Railway. As a part of revitalization works, an old $10 \mathrm{~km}$ railway line was modernized on the Trzęsacz-Pogorzelica route. Moreover, railway rolling stock was renewed by restoring old carriages and equipping them with heating systems and modern toilets, while locomotives and wagons were painted in new colours. Furthermore, historic station buildings were renovated and 3 new stations were built. In 2013, under resolution of council of Rewal municipality, a company called Seaside Narrow-Gauge Railway based in Pogorzelica 
was established. The company is currently an operator of narrow-gauge railway transport on Gryfice-Pogorzelica route (http://morzeprzygody.eu/?page_id=567). Since May 2018, public trains of Seaside Narrow-Gauge Railway have been running daily on the route Gryfice-Trzęsacz (one pair) and Trzęsacz-Pogorzelica (five pairs). The trains are going to run until the end of September. Ticket prices for individual tourists depend on the route section. The carrier offers daily and family tickets (http://morzeprzygody.eu/?page_id=567).

The first line of the Koszalin Narrow Gauge Railway of total length of $32.2 \mathrm{~km}$, from Koszalin to Nacław village, was opened in 1898. However, after the end of the war in 1945 and the takeover of the administration by PKP, all the lines were closed. Some of them were reintroduced only for a short period of time, and in 2001, the last line from Koszalin to Świelino was closed. It was not until 2005 that Towarzystwo Miłośników Koszalińskiej Wąskotorówki (the Association of the Koszalin Narrow-Gauge Railway Enthusiasts) was established, whose main goal is to reactivate the line on the Koszalin-Świelino route. The initial test runs on Koszalin-Manowo took place in 2008. Until today, the association organizes trips to Manowo during summer holidays, also allowing tourists to transport bicycles (http://morzeprzygody.eu/?page_id=567).

Since May 2018, Koszalin narrow-gauge-railway started providing publicly available transport. One pair of trains runs daily between Koszalin-Rosnowo Ośrodek. This several-hour excursion includes various attractions such as visiting hydroelectricity plant or trips with a guide. The tickets can be booked or bought directly at e-podroznik website. Further regular publicly available trains are planned for weekends in June and will operate until the end of September.

In 2011, at the Pomeranian Dukes' Castle in Szczecin, a letter of intent was signed, whose subject was the cooperation within a project called "Revitalization of the closed railway line no. 410 on the section: Połczyn-Zdrój-Złocieniec-Wierzchowo-Mirosławiec-Kalisz PomorskiDrawno-Choszczno-Pełczyce-Barlinek, for the development of active tourism - Bałtycka Kolej Turystyczna". The signatories of the letter included Zachodniopomorskie voivodeship - a supporting entity, Kolej Bałtycka SA (the Baltic Railway SA) - project coordinator, and such municipalities as Barlinek, Choszczno, Drawno, Kalisz Pomorski, Mirosławiec, Pełczyce, Połczyn-Zdrój, Wierzchowo, Złocieniec. The idea is to use the closed railway line no. 410 of total length of $141 \mathrm{~km}$ for the purpose of tourism and creation of a new tourism product - draisine. Such kind of tourism is gaining in popularity in Germany and Scandinavia, whereas in Poland there are already several companies that provide draisine tourism. The basis for development is the takeover of railway lines by the interested entities from their current owner. It is to be hoped that this tourist attraction will become open to public as soon as possible, as narrow-gauge railway managers are aiming at running tourist steam traction trains (Parowozy..., 2018).

\section{Conclusions}

The increased popularity of narrow-gauge railways among tourists corresponds with the general increase in popularity of railways among passengers, especially those travelling for tourist reasons. However, in many cases, the number of passengers using narrow-gauge railways is too 
small to guarantee funds for the proper maintenance of infrastructure and vehicles. The existence of narrow-gauge railways depends on the sources of additional financing. Therefore, local associations and government authorities support the maintenance of tourist narrow-gauge railways. On the other hand, the interest in railway heritage, including steam traction and old devices related to railway traffic, is growing. The rarer these objects become, the more interest they arouse.

On the basis of these considerations, it can be stated that narrow-gauge railway may be developed best when it complements and integrates the tourist offer while simultaneously satisfying the demand for transport services, which, in turn, makes it an integral element of the regional tourism product.

\section{Referencess}

Altkorn, J. (1994). Marketing w turystyce. Warszawa: Wydawnictwo Naukowe PWN.

Analiza walorów turystycznych powiatów i ich bezpośredniego otoczenia (2017). Retrieved from: http://stat.gov.pl/zprac-studialnych/opracowania-eksperymentalne/analiza-walorow-turystycznych-powiatow-i-ich-bezposredniegootoczenia,7,1.html.

Dziedzic, E. (1988). Obszar recepcji turystycznej jako przedmiot zarządzania turystycznego. Monografie i Opracowania, 442.

Gołembski, G. (ed.) (2009). Kompendium wiedzy o turystyce. Warszawa: Wydawnictwo Naukowe PWN.

http://morzeprzygody.eu/?page_id=567.

http://stat.gov.pl/statystyka-regionalna/statystyka-dlapolityki-spojnosci/realizacja-prac-metodologicznych-analizekspertyz-oraz-prac-badawczych-na-potrzeby-politykispojnosci/inne-prace-badawcze.

http://www.turystka07.fora.pl/geografia-turyzmu,32/podstawowe-pojecia-z-geogr-turyzmu-wyklad-ii,154.html (2.06.2018).

https://depot.ceon.pl/.../Atrakcje\%20turystyczne,\%20dziedzictwo\%20i\%20jego\%20int... (3.06.2018).

Kaczmarek, J. (2005). Produkt turystyczny. Pomyst. Organizacja. Zarządzanie. Warszawa: PWE.

Kaczmarek, J., Stasiak, A., Włodarczyk, B. (2002). Produkt turystyczny albo jak organizować poznanie świata. Łódź: Wydawnictwo Uniwersytetu Łódzkiego.

Kaczmarek, J., Stasiak, A., Włodarczyk, B. (2010). Produkt turystyczny. Pomyst-organizacja-zarzqdzanie. Warszawa: PWE.

Kolej waskotorowa w Polsce. Dane rynkowe oraz zasady funkcjonowania, bezpieczeństwo, ochrona dziedzictwa kolei (2017). Warszawa: Urząd Transportu Kolejowego.

Kruczek, Z., Sacha, S. (1997). Geografia atrakcji turystycznych Polski. Kraków: Oficyna Wydawnicza „Ostoja”.

Lijewski, T., Mikułowski, B., Wyrzykowski, J. (2008). Geografia turystyki Polski. Warszawa: PWE.

Marciszewska, B. (2010). Produkt turystyczny a ekonomia doświadczeń. Warszawa: C.H. Beck

Mazurkiewicz, L. (1999). Produkt turystyczny w ujęciu marketingu terytorialnego. In: K. Pieńkos (ed.), Konkurencyjność produktu turystycznego. Warszawa: Wyższa Szkoła Ekonomiczna.

Medlik, S. (1995). Leksykon podróży turystyki hotelarstwa. Warszawa: Wydawnictwo Naukowe PWN.

Meyer, B. (2015). Konsument na rynku usług turystycznych. In: G. Rosa (ed.), Konsument na rynku usług. Warszawa: C.H. Beck.

Meyer, B. (ed.) (2006). Obstuga ruchu turystycznego. Warszawa: Wydawnictwo Naukowe PWN.

Niezgoda, A. (2006). Obszar recepcji turystycznej w warunkach rozwoju zrównoważonego. Poznań: Wydawnictwo Akademii Ekonomicznej w Poznaniu.

Nowacki, M. (2000). Atrakcje turystyczne, dziedzictwo i jego interpretacja.

Parowozy wąkotorowe w 2018 r. (2018). Retrieved from: http://www.rynek-kolejowy.pl/wiadomosci/parowozy-waskotorowe-w-2018-r-87225.html (2.06.2018). 
Pieńkos, K. (ed.) (1999). Konkurencyjność produktu turystycznego. Warszawa: Wyższa Szkoła Ekonomiczna.

Rada Języka Polskiego (2018). Retrieved from: http://www.rjp.pan.pl/index.php?option=com_content\&view=article\&id= 1758:atrakcja-turystyczna\&catid=44\&Itemid=145 (2.06.2018).

Rosa, G., (ed.) (2015). Konsument na rynku ustug. Warszawa: C.H. Beck.

Uniwersalny Stownik Języka Polskiego PWN (2006). Warszawa.

Zdon-Korzeniowska, M. (2009). Jak ksztaltować regionalne produkty turystyczne? Teoria i praktyka. Kraków: Wydawnictwa Uniwersytetu Jagiellońskiego.

Zmyślony, P. (2008). Partnerstwo i przywództwo $w$ regionie turystycznym. Poznań: Wydawnictwo Akademii Ekonomicznej.

Zmyślony, P., Niezgoda, A. (2003). Popyt turystyczny. Uwarunkowania i perspektywy rozwoju. Poznań: Wydawnictwo Akademii Ekonomicznej.

\section{KOLEJ WĄSKOTOROWA JAKO ATRAKCJA TURYSTYCZNA NA PRZYKŁADZIE WOJEWÓDZTWA ZACHODNIOPOMORSKIEGO}

\section{SŁOWA KLUCZOWE \\ STRESZCZENIE}

koleje wąskotorowe, atrakcja turystyczna

W artykule omówiono istotę atrakcji turystycznej jako elementu produktu turystycznego. Przyjęto, że koleje wąskotorowe stanowią często atrakcję turystyczną, ciekawą formę spędzenia wolnego czasu, poznawania zabytków i zakątków przyrody, środek transportu, oraz element tradycji i historii kolejnictwa.

Celem artykułu jest omówienie znaczenia przewozów kolejami wąskotorowymi jako atrakcji turystycznej regionu na przykładzie województwa zachodniopomorskiego. W realizacji celu przyjęto metodę desk research w odniesieniu do dostępnej literatury oraz wyników badań wtórnych prowadzonych na zlecenie Urzędu Transportu Kolejowego oraz GUS. Analiza obejmuje przewozy kolejami wąskotorowymi w Polsce w latach 2014-2016. Artykuł ma charakter badawczy. 